\title{
Efficacy of Phytoextracts against Lesser Grain Borer, Rhizopertha dominica (Fab.) (Coleoptera: Bostrichidae) in Stored Wheat
}

\author{
Dhanraj Parmar, Pradyumn Singh, Ashok S. Yadav*, \\ N.S. Bhadauria and S.S. Bhadauria
}

Department of Entomology, College of Agriculture, RVSKVV, Gwalior (M.P.) 474002, India

*Corresponding author

Keywords

Phytoextracts, Rhizopertha dominica, Stored wheat

Article Info

Accepted: 07 November 2019 Available Online: 10 December 2019

\section{A B S T R A C T}

A laboratory experiment was conducted to evaluate the efficacy of Phytoextracts against Lesser grain borer, Rhizopertha dominica (Fab.) in stored Wheat. Influence of phytoextracts also computed on the basis of adult mortality, emergence and developmental period of Rhizopertha dommica (Fab.). The maximum adult mortality was recorded in ethanol extracts of Neem (90.0\%) followed by Thuja (87.67\%) and Gulabaas $(87.67 \%)$. The highest mortality observed in solvent ethanol in contrast to water extract except Dudhi and Neem. The lowest adult emergence was found in Gulabaas (2.0), Neem (2.0), Thuja (2.0) and Tridex (2.33) with solvent ethanol. The development period was maximum in water extract of Gulabaas (31.7day) among the treatments.

\section{Introduction}

Wheat is a cereal grain of the monocot plant Triticum spp. and it is the world's most important cereal crop in relation to production and consumption. Wheat is grown on more land area than any other commercial crop. It is the most important staple food for humans. Wheat is the leading source of protein in human foods, having higher protein content than either maize or rice, the other major cereal grains. It accounts for an area of 302.27 lakh ha. with production of 93.50 million tones (Anonymous, 2017). The important pest which infest stored wheat in Madhya Pradesh are lesser grain borer Rhizopertha dominica (Fab.), Rice weevil (Sitophilus oryzae Linn), Khapra beetle, (Trogoderma granarium Everts), Angoumois grain moth, (Sitotroga cerealella Oliv) and red rust flour beetle, (Tribolium castaneum Herbst).

The lesser grain borer, Rhizopertha dominica infests large varieties of stored products and is cosmopolitan in their distribution, being much more injurious in warm region of the country. 
About 39 species of insect pests attack the stored grains and grain produce. Out of these the lesser grain borer Rhizopertha dominica (Fab.) is more important, as it is destructive in larval as well as in adult stages. Lesser grain borer Rhizopertha dominica (Fab.) is a field to store pest and this may cause economic damage in the store (Adedire, 2001). The adults are powerful fliers and migrate from one Go down to another, causing fresh infestation. When the infestation is severe, the adults produce a considerable amount of frass, spoiling more than what they eat. The flour, so produced, serves as nourishment for the young grubs until they are ready to bore into the grain. It not only reduces the quantity but also deteriorate the quality of grain and its products (Atwal 1994).

\section{Materials and Methods}

The present investigation was carried out in the Department of Entomology College of Agriculture, Gwalior (M.P.) during 20172018. The mass culture of adults Rhizopertha dominica was collected from infested stocks of wheat from local granaries. The collected adults were released in glass jars having sound grains of wheat variety LOK-1. The containers mouth was tied with muslin cloth than kept at $30^{\circ} \mathrm{C}$ in incubator. All the adults were removed after 5 days of release. The newly emerged adults from the glass jars were utilized for experiment. Materials of ten plants listed in Table 1 were collected from the surrounding of Gwalior. The plant parts were dried at room temperature and then powdered. Their extracts were prepared in water and ethanol as per standard method. The dried extract was again diluted with respective solvent to prepared 5 percent stock solution of each plant extract It was further diluted to 2 percent for seed treatment. Two hundred gram grains of wheat variety Lok-1 were treated with each plant extract @ 4.0 litres extract perquintal grain. These treated grains were used for further experiments. The experiment was conducted under no choice condition and experiment was replicated three times in CRD with 21 treatments. Ten gram grains treated with each plant extract were kept in specimen tubes $(7.5 \times 30 \mathrm{~cm})$ and five pairs of freshly emerged adults of R.dominica were released in each specimen tube. Seventy two hours after released all the adults were removed and the count of dead and alive adults were taken. The tubes were observed daily after 10 days to observe the adult emergence. The number of adults emerged were counted daily, total development period and percent mortality was computed.

The data were subjected to arc sin (angular) or $\sqrt{n+0.5}$ transformation as the case may be before statistical analysis.

\section{Results and Discussion}

\section{Effect of phytoextracts on adult mortality of $R$. dominica}

The adult mortality of $R$. dominica under force condition (Table 2) showed a significant difference among the treatments. The average mortality in treated seeds was ranged from 57 to 90 percent. The highest adult mortality observed in Neem (90\%) followed by Gulabaas (87.67\%), Thuja (87.67\%) and Tridex $(83.33 \%)$ made in ethanol while minimum mortality found in Dudhi (57\%) with solvent water. Among the solvents ethanol made extract was more effective in comparison to extracts of water. Ileke and Daniel S. Bulus (2012) also reported effect of Azadirachta indica powders and extracts on adult mortality against in treated wheat grains.

Effect of phytoextracts on adult emergence of $R$. dominica

The minimum number of adults (2.0) emergence on grains treated with Neem, Thuja 
and Gulabaas extracts of ethonol as against (14.3) in untreated control. The adult emergence declined with increase in adult mortality. Among the phytoextracts made with ethanol significantly lowest number of adults were emergence in Neem (2.0), Thuja (2.0) and Gulabaas (2.0) and at par with other phytoextracts except Chinese glory (5.33) and dudhi (6.67).

However, phytoextracts made with water showed significantly less adults emergence in grain treated with Chinese glory (3.0) and at par with Thuja (4.33), Parthenium (4.33) and Harsinger (4.67) than other phytoextracts.

While phytoextracts made with ethanol maximum adults were emergence in Dudhi (6.67), followed by Chinese glory (5.33). However, phytoextracts made with water showed maximum number of adults emergence in grain treated with Dudhi (8.67) followed by Gulabaas (8.33) and Tridex (7.00).Ileke, D. and Daniel, S. Bulus (2012) found effectiveness of powders and extracts of Azadirachta indica against adult emergence of Rhizopertha dominica in wheat grains.
Effect of phytoextracts on development period of $R$. dominica

All the treatments were significantly differed on development period of Rhizopertha dominica from egg to adult. The less developmental period of Rhizopertha dominica was recorded in seeds treated with Chinese glory (24.7 days) and Gulabaas (25.3 days) in comparison to other treatments while developmental period was increase in Tidex (30.3 days) than other phytoextracts, made with ethanol. Phytoextract made with solvent water less developmental period was noticed in Chinese glory (27.3 days) but more developmental period was in Gulabaas (31.7 days) and Neem (30.3 days) with in comparison to other treatments.

On the other hand phytoextracts made with ethanol significantly less developmental period were found (24.7 days) on grains treated with Chinese glory and at par with Gulabaas, Vishakhapra and Parthenium. However, phytoextracts made with water showed minimum developmental period in grain treated with Chinese glory (27.3) followed by Dudhi and Harsingar.

Table.1 Phytoextracts used against Rhizopertha dominica(Fab.)

\begin{tabular}{|c|c|c|c|}
\hline S. No & Common name of plants & Botanical name of plants & Used of plant parts \\
\hline $\mathbf{1 .}$ & Gulabaas & Mirabilis jalapa & Leaves \\
\hline $\mathbf{2 .}$ & Neem & Azadirachtaindica & Kernel \\
\hline $\mathbf{3 .}$ & Chinese glory & Clerodendruminerme & Leaves \\
\hline $\mathbf{4 .}$ & Harsingar & Thusaoccidentalis & Leaves \\
\hline $\mathbf{5 .}$ & Thuja & Boerhaviadiffusa & Leaves \\
\hline $\mathbf{6 .}$ & Vishkhapra & Euphorbia hirta & Foliage \\
\hline $\mathbf{7 .}$ & Dudhi & Tridexprocumbens & Foliage \\
\hline $\mathbf{8 .}$ & Tridex & Partheniumhysterophorus & Foliage \\
\hline $\mathbf{9 .}$ & Parthenium & Brassica campestris & Seed \\
\hline $\mathbf{1 0 .}$ & Brassica & & \\
\hline $\mathbf{1 1 .}$ & Control & & \\
\hline
\end{tabular}


Table.2 Efficacy of Phytoextracts against Rhizopertha dominica (Fab.)in Stored Wheat

\begin{tabular}{|c|c|c|c|c|}
\hline S. No. & Name of Phytoextracts & $\begin{array}{c}\text { Adult Mortality } \\
(\%)\end{array}$ & $\begin{array}{c}\text { Adult emergence } \\
\text { (No) }\end{array}$ & $\begin{array}{l}\text { Developmental } \\
\text { period (Days) }\end{array}$ \\
\hline 1. & $\begin{array}{c}\text { Gulabaas } \\
\text { ( Ethanol extract) }\end{array}$ & $87.67(68.86)^{*}$ & 2.00 & 25.3 \\
\hline 2. & $\begin{array}{c}\text { Neem } \\
\text { (Ethanol extract) }\end{array}$ & $90.00(74.89)$ & 2.00 & 27.3 \\
\hline 3. & $\begin{array}{l}\text { Chinese glory } \\
\text { (Ethanol extract) }\end{array}$ & $73.33(59.01)$ & 5.33 & 24.7 \\
\hline 4. & $\begin{array}{c}\text { Harsingar } \\
\text { ( Ethanol extract) }\end{array}$ & $83.33(66.15)$ & 3.67 & 28.3 \\
\hline 5. & $\begin{array}{c}\text { Thuja } \\
\text { (Ethanol extract) }\end{array}$ & $87.67(68.86)$ & 2.00 & 29.3 \\
\hline 6. & $\begin{array}{c}\text { Vishkhapra } \\
\text { ( Ethanol extract) }\end{array}$ & $73.33(59.21)$ & 4.00 & 26.6 \\
\hline 7. & $\begin{array}{c}\text { Dudhi } \\
\text { (Ethanol extract) }\end{array}$ & $67.67(54.78)$ & 6.67 & 29.3 \\
\hline 8. & $\begin{array}{c}\text { Tridex } \\
\text { (Ethanol extract) }\end{array}$ & $83.33(66.64)$ & 2.33 & 30.3 \\
\hline 9. & $\begin{array}{c}\text { Parthenium } \\
\text { ( Ethanol extract) }\end{array}$ & $83.33(66.64)$ & 2.33 & 25.3 \\
\hline 10. & $\begin{array}{c}\text { Brassica } \\
\text { (Ethanol extract) }\end{array}$ & $80.00(63.93)$ & 3.00 & 29.3 \\
\hline 11. & $\begin{array}{c}\text { Gulabaas } \\
\text { (Water extract) }\end{array}$ & $80.00(63.93)$ & 8.33 & 31.7 \\
\hline 12. & $\begin{array}{c}\text { Neem } \\
\text { (Water extract) }\end{array}$ & $73.33(59.21)$ & 5.33 & 30.3 \\
\hline 13. & $\begin{array}{c}\text { Chinese glory (Water } \\
\text { extract) }\end{array}$ & $73.33(59.01)$ & 3.00 & 27.3 \\
\hline 14. & $\begin{array}{c}\text { Harsingar } \\
\text { (Water extract) }\end{array}$ & $77.67(61.22)$ & 4.67 & 28.3 \\
\hline 15. & $\begin{array}{c}\text { Thuja } \\
\text { (Water extract) }\end{array}$ & $70.00(56.78)$ & 4.33 & 30.7 \\
\hline 16. & $\begin{array}{c}\text { Vishkhapra } \\
\text { (Water extract) }\end{array}$ & $77.67(61.22)$ & 6.67 & 30.7 \\
\hline 17. & $\begin{array}{c}\text { Dudhi } \\
\text { (Water extract) }\end{array}$ & $57.67(48.84)$ & 8.67 & 28.3 \\
\hline 18. & $\begin{array}{c}\text { Tridex } \\
\text { (Water extract) }\end{array}$ & $67.67(54.78)$ & 7.00 & 30.0 \\
\hline 19. & $\begin{array}{c}\text { Parthenium } \\
\text { (Water extract) }\end{array}$ & $70.00(56.99)$ & 4.33 & 30.3 \\
\hline 20. & $\begin{array}{c}\text { Brassica } \\
\text { (Water extract) }\end{array}$ & $70.00(56.99)$ & 5.33 & 29.0 \\
\hline \multirow[t]{3}{*}{21.} & Control & $03.33(6.37)$ & 14.3 & 28.7 \\
\hline & SE.(m) \pm & 3.76 & 0.79 & 0.76 \\
\hline & C.D. at $5 \%$ & 10.73 & 2.31 & 2.22 \\
\hline
\end{tabular}

*Values in parenthe*sis are arc sine transformed value 
Maximum developmental period was found in grain treated with Tridex (30.3), followed by Brassica and Thuja in phytoextracts made with ethanol. However, Gulabaas (8.67) followed by Thuja and Vishkhapra showed maximum developmental period in phytoextract made with water.

Development period of $R$. dominica showed significant difference among the treatments. The ethanol extract of Tridex and Thuja water extract of Gulabaas and Vishkhapra showed longer development period of $R$. dominica. While ethanol extract of Chinese glory and Parthenium, water extract of Chinese glory and Dudhi showed shorter the development period of $R$. dominica. A reduction in developmental period was observed in rest combination of the treatments in comparison to control. All phytoextracts which were made in ethanol shows shorter development period of adults in contrast to phytoextracts which were made in water. The effect of phytoextracts on adult mortality, adult emergence and development period of Rhizopertha dominica had been reported by Beris et al., (2013) and Shemais et al., (2001).

\section{References}

Adedire, C. O. (2001). pests of stored cereals and pulses in Nigeria in : Ofuya T.I. and Lale N.E.S. biology, Ecology and control of insect pests of stored grains. Nigeria. Dave Collins publication. pp., 59-94.

Anonymous, (2017). Annual report (20162017). Department of Agriculture and Cooperation, Ministry of Agriculture, Government of India. Krishi Bhawan, New Delhi, pp. 4.

Atwal, A. S. (1994). "Insect pest of stored grain and other products: Agricultural pest of India and South East Asia", National Book Foundation, 2 : pp. 402-405.

Beris, G., Ferizli, A G. and Emekci, M. (2013) Effects of diatomaceous earth on the mortality and progeny production of Rhizopertha dominica (Coleoptera: Bostrychidae).

TarimBilimleriDergisi.;17 (2): 85-94.

Ileke, D. and Daniel S. Bulus (2012).Response of Lesser Grain Borer, Rhizopertha dominica (Fabr.) [Coleoptera: Bostrichidae] to Powders and Extracts of Azadirachta indica and Piper guineense Seeds Jordan J. of Biological Sci.; 4 (5): 315 - 320

Shemais, S.A. (2001). Toxicity of Capparis capparis spinosa seed extract to the lesser grain borer, $R$. dominica $(\mathrm{F}$.$) .$ Laboratory evaluation. Egy.-J. of Agric. Res.; 79(2) 481 - 488.

\section{How to cite this article:}

Dhanraj Parmar, Pradyumn Singh, Ashok S. Yadav, N. S. Bhadauria and Bhadauria, S. S. 2019. Efficacy of Phytoextracts against Lesser Grain Borer, Rhizopertha dominica (Fab.) (Coleoptera: Bostrichidae) in Stored Wheat. Int.J.Curr.Microbiol.App.Sci. 8(12): 717-721. doi: https://doi.org/10.20546/ijcmas.2019.812.094 